Research Square
Preprints are preliminary reports that have not undergone peer review.

They should not be considered conclusive, used to inform clinical practice, or referenced by the media as validated information.

\title{
A Single Preoperative Dose and an Additional Dose of Tranexamic Acid in Total Knee Arthroplasty: a Meta-analysis
}

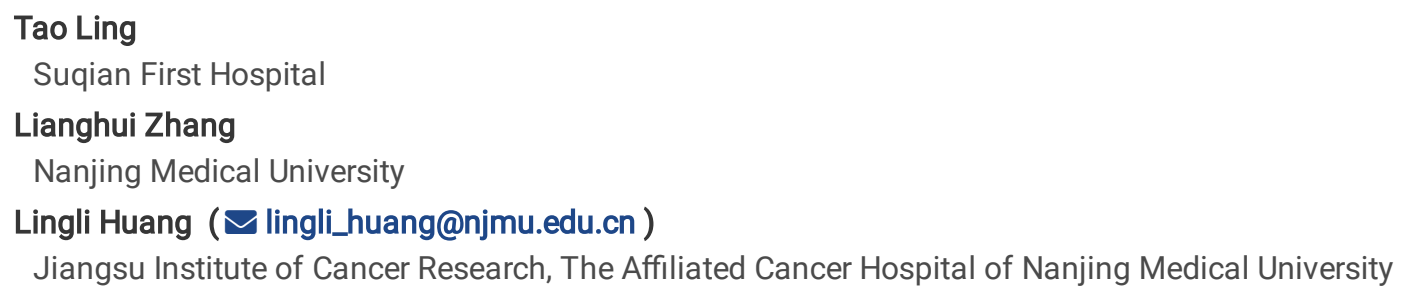




\section{Abstract}

Objective: To review the efficacy and safety of a single preoperative dose and an additional postoperative dose of tranexamic acid (TXA) in reducing blood loss in total knee arthroplasty (TKA).

Methods: PubMed, Embase, Cochrane Library and Web of Science were searched for randomized controlled trials (RCTs) in March 2021. Postoperative blood loss, transfusion rate, and deep vein thrombosis (DVT) incidence were studied. Data were analyzed using Review Manager 5.3 software and Stata 14.0 software.

Results: Intravenous (IV) TXA twice provided lower postoperative blood loss compared with placebo group (P凶0.001) and IV TXA once group ( $\mathrm{P}=0.007)$, but a higher postoperative blood loss as compared with combined TXA (P凶0.001). IV TXA twice provided lower transfusion rate compared with placebo group (Pख0.001). No significant difference was found in terms of DVT incidence (Pख0.05). There was no significant publication bias for postoperative blood loss, transfusion rate, and DVT incidence.

Conclusion: When it comes to IV TXA in TKA, a single preoperative dose and an additional dose of TXA may be a better and more feasible way for blood control than a single preoperative dose.

\section{Introduction}

Total knee arthroplasty (TKA) is one of the most commonly performed orthopedic surgery, which is associated with a series of postoperative complications including blood loss[1, 2]. Intraoperative and postoperative bleeding is one of the main complications in TKA, and various blood-conserving strategies have been used in TKA. Hyperfibrinolysis following surgery is a major contributor to perioperative blood loss in TKA[3]. Tranexamic acid (TXA), a commonly used antifibrinolytic agent, inhibits fibrinolysis by blocking the lysine-binding site of plasminogen and has become the method of choice for controlling blood loss[4, 5]. Several studies have shown that intravenous (IV)[68], intra-articular (IA) [9-11] or oral[12-14] application of TXA can successfully reduce blood loss and transfusion rate in primary TKA without increasing the risk of thrombosis. But the most effective administration route of TXA remains controversial.

Recently, a meta-analysis[15] assessed the efficacy and safety of the efficacy and safety of a single dose of IV TXA given preoperatively. and it showed that preoperative IV TXA reduced perioperative blood loss and transfusion requirements in a variety of surgical disciplines without increasing the risk of thromboembolic events.

One RCT[7] showed that with the same total dose of TXA, the preoperative dose and an additional dose of TXA (IV TXA twice) were superior to a single preoperative dose of TXA (IV TXA once) in reducing blood loss in TKA. So this study aimed to assess the effect of a single preoperative dose and an additional postoperative dose of tranexamic acid more comprehensively. Postoperative blood loss, transfusion rate, and complication such as DVT incidence were the efficacy and safety points, respectively.

\section{Methods}

\section{Search Strategy}

The literature search using Embase, Cochrane Library, PubMed, and Web of Science databases until May 2021 were conducted. The search strategy included key search terms: ("tranexamic acid" or "TXA" or "TA") and ("total knee arthroplasty" or "total knee replacement" or "TKA" or "TKR"). and ("randomized controlled trial" or "RCT"). Besides, the reference lists of previously published randomized trials, review articles, and meta-analyses were manually searched for additional eligible studies. Related articles and reference lists were searched to avoid original miss. Duplicate records were removed electronically and manually.

\section{Eligibility Criteria}

All citations were downloaded into Endnote X9. Two reviewers (LT and ZL) performed study selection independently, with disagreements solved through discussions and by consulting a third reviewer $(\mathrm{HL})$ if necessary. The inclusion criteria for these studies were performed as follows: (1) Studies on patients with TKA; (2) RCTs; (3) IV TXA twice as intervening measure; (4) Studies reporting postoperative blood loss, transfusion rate, or DVT incidence. The exclusion criteria were: (1) Secondary analyses, including some pooled analyses; (2) Studies published not in English; (3) Abstract, case reports, letters, editorials, conference articles, or insufficient data.

\section{Quality Assessment}

The Cochrane risk of bias assessment tool was used to determine the methodological quality of included RCTs [16]. A total of six domains were evaluated: random sequence generation, allocation concealment, participant blinding, outcome assessor blinding, incomplete 
outcome data and selective reporting. Each domain was assigned a judgment of low risk of bias, high risk of bias or unclear risk of bias. The judgments for each domain were made by strictly following the Cochrane Handbook V.5.1.0, Chapter 8.5.

\section{Data Extraction}

The following data were extracted: (1) Characteristics of the 24 trials selected showing general surgical information; (2) Outcome measures including postoperative blood loss, transfusion rate, and DVT incidence; (3) For continuous outcomes, we extracted the mean and standard deviation (SD). For dichotomous outcomes, we extracted the total numbers and the numbers of events in both groups.

\section{Statistical Analysis}

Heterogeneity among studies was tested using the $Q$ statistic $(P<0.05$ was considered heterogeneous $)$ and $\mathrm{I}^{2}$ statistic $\left(\mathrm{I}^{2}>50 \%\right.$ was considered heterogeneous). If there was no significant heterogeneity among studies, a fixed-effects model was used; otherwise, a randomeffects model was used[17]. The effect of publication bias was investigated by Egger's test[18]. Mean difference (MD) was calculated for continuous outcomes, and risk ratio (RR) was calculated for dichotomous outcomes. Statistical analyses were conducted using Review Manager 5.3 software (RevMan5.3, Cochrane Collaboration, Oxford, UK) and Stata software (Version 14.0, College Station, TX, USA).

\section{Results}

\section{Study Characteristics and Quality Assessment}

A total of 1754 potentially relevant articles were identified from the databases. After removal of duplicates, 1251 articles were screened for relevance in terms of the title and abstract. And then 109 articles were read the full text and 26 articles were reserved, in which 24 of them possibly eligible for inclusion. Two studies were excluded for reasons of "No available data" (Details are shown in Fig. 1). The remaining 24 RCTs were included in this meta-analysis. The characteristics of the ten included studies were summarized and showed in Table 1. The quality assessment of RCTs is presented in Fig. 2. 
Table 1

Characteristics of the 16 trials selected showing general surgical information

\begin{tabular}{|c|c|c|c|c|c|c|c|}
\hline Study & $\begin{array}{l}\text { Experiment } \\
\text { group }\end{array}$ & $\begin{array}{l}\text { Blank } \\
\text { control }\end{array}$ & $\begin{array}{l}\text { TXA } \\
\text { control } \\
\text { group }\end{array}$ & Tourniquet & Thromboprophylaxis & $\begin{array}{l}\text { DVT } \\
\text { screening }\end{array}$ & $\begin{array}{l}\text { Allogeneic } \\
\text { transfusion } \\
\text { criteria }\end{array}$ \\
\hline Wang2019[22] & $\begin{array}{l}\text { IV } \\
20 \mathrm{mg} / \mathrm{kg} \\
\text { TXA twice }\end{array}$ & & $\begin{array}{l}\text { IV } \\
20 \mathrm{mg} / \mathrm{kg} \\
\text { TXA } \\
\text { twice } \ 1 \mathrm{~g} \\
\text { TXA } \\
\text { orally } 14 \\
\text { times }\end{array}$ & no & $\begin{array}{l}\text { LMWH and a venous } \\
\text { pump }\end{array}$ & $\begin{array}{l}\text { doppler } \\
\text { ultrasound }\end{array}$ & $\begin{array}{l}\mathrm{Hb}<70 \mathrm{~g} / \mathrm{L} \text { in } \\
\text { asymptomatic or } \\
\text { between } 70 \mathrm{~g} / \mathrm{L} \\
\text { and } 100 \mathrm{~g} / \mathrm{L} \text { in } \\
\text { symptomatic } \\
\text { patients }\end{array}$ \\
\hline Tzatzairis2019[28] & $\begin{array}{l}\text { IV } \\
15 \mathrm{mg} / \mathrm{kg} \\
\text { TXA twice }\end{array}$ & & $\begin{array}{l}\text { IV } \\
15 \mathrm{mg} / \mathrm{kg} \\
\text { TXA }\end{array}$ & no & $\begin{array}{l}\text { LMWH and } \\
\text { compression } \\
\text { stockings }\end{array}$ & $\begin{array}{l}\text { CT/Doppler } \\
\text { ultrasound }\end{array}$ & $\begin{array}{l}\mathrm{Hb}<10 \mathrm{~g} / \mathrm{dl} \text { or } \\
\text { any anemic } \\
\text { symptoms or } \\
\text { anemia-related } \\
\text { organ } \\
\text { dysfunction }\end{array}$ \\
\hline Takuya2018[23] & $\begin{array}{l}\text { IV } 1 \mathrm{~g} \text { TXA } \\
\text { twice }\end{array}$ & & $\begin{array}{l}\text { IV } 1 \mathrm{~g} \\
\text { TXA } \\
\text { twice } \mathrm{IA} \\
\text { 1g TXA }\end{array}$ & no & $\begin{array}{l}\text { fondaparinux once } \\
\text { every evening for } 7 \\
\text { days }\end{array}$ & NR & $\begin{array}{l}\mathrm{Hb}<7 \mathrm{~g} / \mathrm{dL} \text { in } \\
\text { asymptomatic or } \\
\text { those with } \\
\mathrm{Hb}<10 \mathrm{~g} / \mathrm{dL} \text { if } \\
\text { they had } \\
\text { symptoms }\end{array}$ \\
\hline Yuan2017[14] & $\begin{array}{l}\text { IV } \\
20 \mathrm{mg} / \mathrm{kg} \\
\text { TXA twice }\end{array}$ & placebo & $\begin{array}{l}3 \mathrm{~g} \\
\text { topical } \\
\text { TXA }\end{array}$ & yes & $\begin{array}{l}\text { venous pump and } \\
\text { rivaroxaban }\end{array}$ & $\begin{array}{l}\text { doppler } \\
\text { ultrasound }\end{array}$ & $\begin{array}{l}\mathrm{Hb}<8.0 \mathrm{~g} / \mathrm{dL} \text { or } \\
\text { symptoms }\end{array}$ \\
\hline $\begin{array}{l}\text { Sun2017 } \\
\text { [7] }\end{array}$ & $\begin{array}{l}\text { IV } \\
15 \mathrm{mg} / \mathrm{kg} \\
\text { two times }\end{array}$ & saline & $\begin{array}{l}\text { IV } \\
30 \mathrm{mg} / \mathrm{kg}\end{array}$ & yes & $\begin{array}{l}\text { LMWH for } 3 \text { days, } \\
\text { and then } \\
\text { rivaroxaban for } 1 \\
\text { month }\end{array}$ & $\begin{array}{l}\text { doppler } \\
\text { ultrasound }\end{array}$ & $\begin{array}{l}\mathrm{Hb}<8 \mathrm{~g} / \mathrm{dL} \text { or } \\
10 \mathrm{~g} / \mathrm{dL} \text { and } \\
\text { complicated } \\
\text { with intolerable } \\
\text { ischemic } \\
\text { symptoms }\end{array}$ \\
\hline Lee2017[24] & $\begin{array}{l}\text { IV } \\
10 \mathrm{mg} / \mathrm{kg} \\
\text { twice }\end{array}$ & & $\begin{array}{l}\text { IV } \\
10 \mathrm{mg} / \mathrm{kg} \\
\text { twicelIA } \\
1 \mathrm{~g} \text { TXA }\end{array}$ & yes & $\begin{array}{l}\text { individualized } \\
\text { approach protocol }\end{array}$ & NR & $\begin{array}{l}\mathrm{Hb}<7 \mathrm{~g} / \mathrm{dL} \text { or if } \\
\text { anemic } \\
\text { symptoms in } \\
\text { patients with } \mathrm{Hb} \\
\text { between } 7.0 \text { and } \\
8.0 \mathrm{mg} / \mathrm{dL}\end{array}$ \\
\hline Lacko2017[29] & $\begin{array}{l}\text { IV } \\
10 \mathrm{mg} / \mathrm{kg} \\
\text { twice }\end{array}$ & $\begin{array}{l}\text { normal } \\
\text { saline }\end{array}$ & $\begin{array}{l}\text { IA } 3 g \\
\text { TXA }\end{array}$ & yes & NR & $\begin{array}{l}\text { ultrasound of } \\
\text { the venous } \\
\text { system }\end{array}$ & $\begin{array}{l}\mathrm{Hb}<8 \mathrm{~g} / \mathrm{dL} \text { or }<9 \\
\mathrm{~g} / \mathrm{dL} \text { when the } \\
\text { patient had } \\
\text { simultaneous } \\
\text { signs of } \\
\text { postoperative } \\
\text { anemia }\end{array}$ \\
\hline $\begin{array}{l}\text { Castro- } \\
\text { Menendez2016[30] }\end{array}$ & $\begin{array}{l}\text { IV } 1 \mathrm{~g} \text { TXA } \\
\text { twice }\end{array}$ & placebo & $\begin{array}{l}\text { IV } 2 g \\
\text { TXA }\end{array}$ & yes & $\begin{array}{l}3500 \text { UI Bemiparin } \\
\text { Sodium were used } \\
35 \text { days }\end{array}$ & $\begin{array}{l}\text { doppler } \\
\text { ultrasound }\end{array}$ & $\begin{array}{l}\mathrm{Hb}<8 \mathrm{~g} / \mathrm{dl} \text { in } \\
\text { healthy patients } \\
\text { without } \\
\text { preoperative } \\
\text { cardiopulmonary } \\
\text { pathology, or } \\
\mathrm{Hb}<9 \mathrm{~g} / \mathrm{dl} \text { with } \\
\text { clinical } \\
\text { symptoms of } \\
\text { haemodynamic } \\
\text { instability }\end{array}$ \\
\hline May2016[31] & $\begin{array}{l}\text { IV } 1 \mathrm{~g} \text { TXA } \\
\text { twice }\end{array}$ & & $\begin{array}{l}\text { IA } 2 g \\
\text { TXA }\end{array}$ & yes & $\begin{array}{l}\text { LMWH or oral direct } \\
\text { factor Xa inhibitor }\end{array}$ & NR & $\begin{array}{l}\mathrm{Hb}<7 \mathrm{~g} / \mathrm{dL} \text { or } \\
\mathrm{Hb}<10 \mathrm{~g} / \mathrm{dL} \text { if } \\
\text { they had } \\
\text { symptoms or } \\
\text { ongoing blood } \\
\text { loss }\end{array}$ \\
\hline
\end{tabular}




\begin{tabular}{|c|c|c|c|c|c|c|c|}
\hline Study & $\begin{array}{l}\text { Experiment } \\
\text { group }\end{array}$ & $\begin{array}{l}\text { Blank } \\
\text { control }\end{array}$ & $\begin{array}{l}\text { TXA } \\
\text { control } \\
\text { group }\end{array}$ & Tourniquet & Thromboprophylaxis & $\begin{array}{l}\text { DVT } \\
\text { screening }\end{array}$ & $\begin{array}{l}\text { Allogeneic } \\
\text { transfusion } \\
\text { criteria }\end{array}$ \\
\hline Motififard2015[32] & $\begin{array}{l}\text { IV } 0.5 \mathrm{~g} \\
\text { TXA twice }\end{array}$ & saline & & yes & LMWH for 14 days & NR & $\begin{array}{l}\mathrm{Hb}<8 \mathrm{~g} / \mathrm{dL} \text { or } \\
10 \mathrm{~g} / \mathrm{dL} \text { in } \\
\text { patients with } \\
\text { comorbidities } \\
\text { and untolerated } \\
\text { anemic } \\
\text { symptoms }\end{array}$ \\
\hline Aguilera2015[33] & $\begin{array}{l}\text { IV } 1 \mathrm{~g} \text { TXA } \\
\text { twice }\end{array}$ & & $\begin{array}{l}1 \mathrm{~g} \\
\text { topical } \\
\text { TXA(by } \\
\text { syringe- } \\
\text { spray to } \\
\text { the } \\
\text { following } \\
\text { surfaces) }\end{array}$ & yes & LMWH & NR & $\begin{array}{l}\mathrm{Hb}<8 \text { or } 8.5 \mathrm{~g} / \mathrm{dL} \\
\text { in patients with } \\
\text { heart disease or } \\
\text { older than } 70 \\
\text { years or when } \\
\text { Hb between } 8.5 \\
\text { and } 9 \mathrm{~g} / \mathrm{dL} \text { in } \\
\text { patients with low } \\
\text { orthostatic } \\
\text { tolerance }\end{array}$ \\
\hline Kim2014[34] & $\begin{array}{l}\text { IV } \\
10 \mathrm{mg} / \mathrm{kg} \\
\text { twice }\end{array}$ & saline & & yes & $\begin{array}{l}\text { orthopaedic } \\
\text { Surgeons' Clinical } \\
\text { Guidelines }\end{array}$ & NR & $\begin{array}{l}\mathrm{Hb}<7 \mathrm{mg} / \mathrm{dL} \text { or if } \\
\text { anaemic } \\
\text { symptoms in } \\
\text { patients with an } \\
\mathrm{Hb} \text { between } 7 \\
\text { and } 8 \mathrm{mg} / \mathrm{dL}\end{array}$ \\
\hline $\begin{array}{l}\text { Gomez- } \\
\text { Barrena2014[26] }\end{array}$ & $\begin{array}{l}\text { IV } \\
15 \mathrm{mg} / \mathrm{kg} \\
\text { TXA twice }\end{array}$ & & $\begin{array}{l}\text { IA } 3 g \\
\text { TXA }\end{array}$ & yes & $\begin{array}{l}40 \mathrm{mg} \text { enoxaparin } \\
\text { for two weeks }\end{array}$ & NR & $\begin{array}{l}\mathrm{Hb}<8 \mathrm{~g} / \mathrm{dL} \text { or } \\
\mathrm{Hb}<10 \mathrm{~g} / \mathrm{dL} \text { if } \\
\text { they had } \\
\text { symptoms or } \\
\text { ongoing blood } \\
\text { loss }\end{array}$ \\
\hline Bidolegui2014[35] & $\begin{array}{l}\text { IV } \\
15 \mathrm{mg} / \mathrm{kg} \\
\text { TXA twice }\end{array}$ & placebo & & no & $\begin{array}{l}40 \mathrm{mg} \text { enoxaparin } \\
\text { for } 30 \text { days }\end{array}$ & NR & $\begin{array}{l}\mathrm{Hb}<8 \text { or } 9 \mathrm{~g} / \mathrm{dl} \\
\text { associated with } \\
\text { either patients } \\
\text { instability or } \\
\text { with prior } \\
\text { cardiac history }\end{array}$ \\
\hline Lee2013[36] & $\begin{array}{l}\text { IV } \\
10 \mathrm{mg} / \mathrm{kg} \\
\text { TXA twice }\end{array}$ & saline & & yes & $\begin{array}{l}2.5 \mathrm{mg} \\
\text { fondaparinux } \\
\text { for } 5 \text { days }\end{array}$ & $\begin{array}{l}\text { doppler } \\
\text { ultrasound }\end{array}$ & $\begin{array}{l}\mathrm{Hb}<8 \mathrm{~g} / \mathrm{dL} \text { or } \\
\text { clinical } \\
\text { symptoms of }\end{array}$ \\
\hline Aguilera2013[37] & $\begin{array}{l}\text { IV } 1 \mathrm{~g} \text { TXA } \\
\text { twice }\end{array}$ & placebo & & yes & LMWH for 30 days & NR & $\begin{array}{l}\mathrm{Hb}<8 \text { or } 8.5 \mathrm{~g} / \mathrm{dL} \\
\text { in patients with } \\
\text { heart disease or } \\
\text { older than } 70 \\
\text { years or when } \\
\text { Hb between } 8.5 \\
\text { and } 9 \mathrm{~g} / \mathrm{dL} \text { in } \\
\text { patients with low } \\
\text { orthostatic } \\
\text { tolerance }\end{array}$ \\
\hline Maniar2012[38] & $\begin{array}{l}\text { IV } \\
10 \mathrm{mg} / \mathrm{kg} \\
\text { TXA twice }\end{array}$ & saline & $\begin{array}{l}\text { IV } \\
10 \mathrm{mg} / \mathrm{kg} \\
\text { TXA }\end{array}$ & yes & $\begin{array}{l}\text { LMWH and below- } \\
\text { knee stockings }\end{array}$ & NR & $\begin{array}{l}\mathrm{Hb}<8.5 \mathrm{~g} / \mathrm{dL} \text { or } \\
\text { patients with } \\
\text { cardiac } \\
\text { disorders whose } \\
\mathrm{Hb}<10 \mathrm{~g} / \mathrm{dL} \text { or } \\
\text { patients whose } \\
\mathrm{Hb} 8.5 \text { to } 10 \mathrm{~g} / \mathrm{dL} \\
\text { but had } \\
\text { symptoms. }\end{array}$ \\
\hline
\end{tabular}

LMWH: low molecular weight heparin; NR: not reported; S.C.: Subcutaneous injection. 


\begin{tabular}{|c|c|c|c|c|c|c|c|}
\hline Study & $\begin{array}{l}\text { Experiment } \\
\text { group }\end{array}$ & $\begin{array}{l}\text { Blank } \\
\text { control }\end{array}$ & $\begin{array}{l}\text { TXA } \\
\text { control } \\
\text { group }\end{array}$ & Tourniquet & Thromboprophylaxis & $\begin{array}{l}\text { DVT } \\
\text { screening }\end{array}$ & $\begin{array}{l}\text { Allogeneic } \\
\text { transfusion } \\
\text { criteria }\end{array}$ \\
\hline $\begin{array}{l}\text { Lin2012 } \\
\text { [39] }\end{array}$ & $\begin{array}{l}\text { IV } \\
10 \mathrm{mg} / \mathrm{kg} \\
\text { TXA twice }\end{array}$ & saline & $\begin{array}{l}\text { IV } \\
10 \mathrm{mg} / \mathrm{kg} \\
\text { TXA }\end{array}$ & yes & $\begin{array}{l}20 \mathrm{mg} \text { enoxaparin } \\
\text { until discharge }\end{array}$ & $\begin{array}{l}\text { Antegrade } \\
\text { enography/CT }\end{array}$ & $\begin{array}{l}\mathrm{Hb}<8 \mathrm{~g} / \mathrm{dl} \text { or } \\
\text { between } 8 \mathrm{~g} / \mathrm{dl} \\
\text { and } 9 \mathrm{~g} / \mathrm{dl} \text { in } \\
\text { patients with } \\
\text { symptoms or } \\
\text { cardiovascular } \\
\text { disease }\end{array}$ \\
\hline Molloy2007[40] & $\begin{array}{l}\text { IV } 0.5 \mathrm{~g} \\
\text { TXA twice }\end{array}$ & placebo & & yes & NR & NR & NR \\
\hline Camarasa2006[41] & $\begin{array}{l}\text { IV } 10 \\
\mathrm{mg} / \mathrm{kg} \\
\text { TXA twice }\end{array}$ & saline & & yes & $\begin{array}{l}\text { s.c. dalteparin } \\
\text { sodium } 5000 \text { IU for } \\
40 \text { days }\end{array}$ & $\begin{array}{l}\text { venous echo- } \\
\text { Doppler }\end{array}$ & $\begin{array}{l}\mathrm{Hb}<8 \mathrm{~g} / \mathrm{dL} \text { or } \\
\mathrm{Hb}<10 \mathrm{~g} / \mathrm{dL} \text { if } \\
\text { they had poor } \\
\text { tolerance }\end{array}$ \\
\hline Good2003[42] & $\begin{array}{l}\text { IV } 10 \\
\mathrm{mg} / \mathrm{kg} \\
\text { TXA twice }\end{array}$ & saline & & yes & $\begin{array}{l}\text { S.C. dalteparin } \\
\text { sodium } 5000 \text { IU for } \\
11 \text { days }\end{array}$ & NR & $\mathrm{Hb}<90 \mathrm{~g} / \mathrm{L}$ \\
\hline Veien2002[43] & $\begin{array}{l}\text { IV } 10 \\
\mathrm{mg} / \mathrm{kg} \\
\text { TXA twice }\end{array}$ & saline & & yes & LMWH & NR & NR \\
\hline Tanaka2001[44] & $\begin{array}{l}\text { IV } 10 \\
\mathrm{mg} / \mathrm{kg} \\
\text { TXA twice }\end{array}$ & saline & $\begin{array}{l}\text { IV } 20 \\
\mathrm{mg} / \mathrm{kg} \\
\text { TXA }\end{array}$ & yes & NR & $\begin{array}{l}\text { radio-isotope } \\
\text { venography }\end{array}$ & NR \\
\hline Benoni1996[45] & $\begin{array}{l}\text { IV } 10 \\
\mathrm{mg} / \mathrm{kg} \\
\text { TXA twice }\end{array}$ & placebo & & yes & LMWH for 7-10 days & NR & NR \\
\hline
\end{tabular}

\section{Meta-analysis of Postoperative Blood Loss}

Postoperative blood loss data were provided by 16 included studies (Fig. 3). Our meta-analysis indicated that patients receiving IV TXA twice had significantly lower postoperative blood loss as compared to the placebo group ( $\mathrm{MD}=-378.28,95 \% \mathrm{Cl}-483.62$ to $-264.91, \mathrm{P}<0.001$; $\left.\mathrm{I}^{2}=88.0 \%, \mathrm{P}<0.001\right)$ or IV TXA once $\left(\mathrm{MD}=-82.32,95 \% \mathrm{Cl}-141.96\right.$ to $\left.-22.67, \mathrm{P}=0.007 ; \mathrm{I}^{2}=0.0 \%, \mathrm{P}=0.75\right)$.

No significant difference was observed in postoperative blood loss (MD=-91.37, 95\% $\mathrm{Cl}-340.03$ to $\left.157.28, P=0.47 ; I^{2}=68.0 \%, P=0.08\right)$ between IV TXA twice and topical TXA. IV TXA once and topical/oral TXA may reduce postoperative blood loss than IV TXA twice $\left(M D=154,43,95 \% \mathrm{Cl} 81.54\right.$ to $\left.227.33, P<0.001 ; I^{2}=48.0 \%, P=0.14\right)$.

\section{Meta-analysis of Transfusion Rate}

Transfusion rate data were provided by 22 included studies (Fig. 4). Our meta-analysis indicated that patients receiving IV TXA twice had significantly lower transfusion rate as compared to the placebo group ( $R R=0.27,95 \% \mathrm{Cl} 0.21$ to $0.34, P<0.001 ; I^{2}=43.0 \%, P=0.03$ ). No significant differences in were observed in IV TXA twice and topical TXA or IV once or topical TXA group.

\section{Meta-analysis of DVT Incidence}

18 randomized studies reported DVT incidence and no significant differences were observed (Fig. 5).

\section{Publication bias}

Egger's test was used to assess the potential publication bias of postoperative blood loss, transfusion rate, and DVT incidence studies included in this meta-analysis. The $\mathrm{P}$ values from Egger's test indicated that there was no significant publication bias for postoperative blood loss, transfusion rate, and DVT incidence $(P=0.936, P=0.224$ and $P=0.705$, respectively).

\section{Discussion}


Allogenic blood transfusions after TKA carried significant potential risks, which should be avoided as well as possible, so TXA should be applied. IV application of TXA has been confirmed as effectively decreasing postoperative blood loss and transfusion rate in TKA patients[19,20]. However, there is no clear consensus on the optimal regimen of IV application of TXA. Administering one pre-operative dose and one subsequent post-operative dose is one of the most common IV application practices. The interval of doses is usually three hours, which is because TXA has a plasma half-life of three hours. This is the first meta-analysis to identify the efficacy and safety of a single preoperative dose and an additional dose of IV TXA in TKA.

This study showed that IV TXA twice could reduce postoperative blood loss than the placebo group and IV TXA once group, which was consistent with those of previous studies[7,21]. There is a difference existing between single dose and multiple doses, and two doses of TXA may be the optimal regimen for blood loss. IV TXA twice had a higher postoperative blood loss as compared with the IV TXA once and topical/oral group, which may due to the total TXA dose. The efficacy of TXA was positively correlated with total dose, and the use of TXA at two intervals could maintain the exposure level of tranexamic acid to systemic circulation in order to achieve a better effect of reducing postoperative bleeding after TKA.

In three RCTs included, IV TXA twice with subsequent TXA was more effective than IV TXA twice group. Wang et al[22] compared IV $20 \mathrm{mg} / \mathrm{kg}$ TXA twice with IV 20mg/kg TXA twice and subsequent long-term oral TXA for 14 days, finding the latter produced less blood loss and less swelling and ecchymosis without increasing the risk of complications. Takuya et al[23] compared IV $1 \mathrm{~g}$ TXA twice with IV $1 \mathrm{~g}$ TXA twice and intra-articular (IA) 1g TXA, showing IV and IA TXA regimen significantly reduced perioperative blood loss compared with only IV TXA. Lee et al[24] compared IV 10mg/kg TXA twice with IV 10mg/kg TXA twice and IA $1 \mathrm{~g}$ TXA, concluding that combined IA TXA administration further reduces blood loss after TKA in comparison to IV use alone. IV TXA twice with subsequent TXA, either oral or IA, and either long or short term, bleeding could be better controlled.

In addition, IV TXA twice had a similar efficacy with topical TXA in terms of reducing postoperative blood loss. One study[25] indicated that topical $1 \mathrm{~g}$ TXA and IV $10 \mathrm{mg} / \mathrm{kg}$ TXA once have similar safety and efficacy for reducing perioperative blood loss in TKA. Gomez-Barrena et al concluded[26] that a single topical dose of $3 \mathrm{~g}$ of TXA was not inferior to two $15 \mathrm{mg} / \mathrm{kg}$ IV TXA doses. We thought IV TXA twice and topical TXA achieved equal control of blood loss. TXA applied locally before wound closure targeted the bleeding, which could reduce the significant increase in local fibrinolysis associated with tourniquet release[27].

IV TXA twice had significantly lower transfusion rate as compared to the placebo group. No significant differences in were observed between IV TXA twice and TXA control group in terms of transfusion rate. No significant differences in were observed in terms of DVT incidence. When the patients determined to apply TXA during the perioperative period, IV TXA twice could be used without without safety concerns. Egger's test indicated that there was no significant publication bias for postoperative blood loss, transfusion rate, and DVT incidence. Therefore, the results of this study were relatively stable.

The authors acknowledge that the current study has several limitations. Firstly, the sample of IV TXA twice in this study was small. Secondly, we only pooled DVT complication. Finally, there may be high quality non-English studies that could have influenced the outcomes of our meta-analysis, but were excluded due to the selection criteria. A longer follow-up period is required to compare the safety profile and functional outcome differences.

\section{Conclusion}

When it comes to IV TXA in TKA, a single preoperative dose and an additional dose of TXA may be a better and more feasible way for blood control than a single preoperative dose.

\section{Declarations}

The authors declared that they had no known competing financial interests or personal relationships that could have appeared to influence the work reported in this paper. All methods in the included studies of this meta-analysis were carried out in accordance with relevant guidelines and regulations.

\section{Ethics approval and consent to participate}

Not applicable.

\section{Consent for publication}


Not applicable.

Availability of data and materials

All relevant data (including raw-data) has been provided in figures, tables and supplements.

Competing interests

The authors declare that they have no competing interests.

Funding

No.

Authors' contributions

All authors have full access to all data in the study. LT and ZL conducted the literatures screening and the statistical analysis. $L T$ and $H L$ wrote the manuscript. ZL reviewed the manuscript. All Authors read and approved the final version of the manuscript.

Acknowledgements

The authors acknowledge the contribution of Xiaoyaojun Zixishi (WeChat ID: ixiaoyaojun), WeChat subscription.

\section{References}

1. Sadigursky D, Araujo LM, Carneiro Fernandes RJ: Efficacy of tranexamic acid in reducing blood loss in total knee arthroplasty. Acta Ortopedica Brasileira 2018, 26(1):63-66.

2. Ng W, Jerath A, Wasowicz M: Tranexamic acid: a clinical review. Anaesthesiology intensive therapy 2015, 47(4):339-350.

3. Tang Y, Wen Y, Li W, Li H, Yang Y, Liu Y: The efficacy and safety of multiple doses of oral tranexamic acid on blood loss, inflammatory and fibrinolysis response following total knee arthroplasty: A randomized controlled trial. International Journal of Surgery 2019, 65:4551.

4. McCormack PL: Tranexamic Acid A Review of its Use in the Treatment of Hyperfibrinolysis. Drugs 2012, $72(5): 585-617$.

5. Dunn CJ, Goa KL: Tranexamic acid: a review of its use in surgery and other indications. Drugs 1999, 57(6):1005-1032.

6. Sun Q, Yu X, Nie X, Gong J, Cai M: The Efficacy Comparison of Tranexamic Acid for Reducing Blood Loss in Total Knee Arthroplasty at Different Dosage Time. Journal of Arthroplasty 2017, 32(1):33-36.

7. Sun Q, Yu X, Wu J, Ge W, Cai M, Li S: Efficacy of a Single Dose and an Additional Dose of Tranexamic Acid in Reduction of Blood Loss in Total Knee Arthroplasty. Journal of Arthroplasty 2017, 32(7):2108-2112.

8. Seviciu A, Gross I, Fathima S, Walsh SM: Effects of tranexamic acid and bipolar sealer alone or in combination in primary total knee arthroplasty: a prospective, randomized, controlled trial. Arthroplasty today 2016, 2(2):77-82.

9. Guerreiro JPF, Badaro BS, Balbino JRM, Danieli MV, Queiroz AO, Cataneo DC: Application of Tranexamic Acid in Total Knee Arthroplasty - Prospective Randomized Trial. The open orthopaedics journal 2017, 11:1049-1057.

10. Wang CG, Sun ZH, Liu J, Cao JG, Li ZJ: Safety and efficacy of intra-articular tranexamic acid injection without drainage on blood loss in total knee arthroplasty: A randomized clinical trial. International journal of surgery (London, England) 2015, 20:1-7.

11. Wang G, Wang D, Wang B, Lin Y, Sun S: Efficacy and safety evaluation of intra-articular injection of tranexamic acid in total knee arthroplasty operation with temporarily drainage close. International Journal of Clinical and Experimental Medicine 2015, 8(8):1432814334.

12. Alipour M, Tabari M, Keramati M, Zarmehri AM, Makhmalbaf H: Effectiveness of oral Tranexamic acid administration on blood loss after knee artroplasty: A randomized clinical trial. Transfusion and Apheresis Science 2013, 49(3):574-577.

13. Charoencholvanich K, Siriwattanasakul P: Tranexamic Acid Reduces Blood Loss and Blood Transfusion after TKA: A Prospective Randomized Controlled Trial. Clinical Orthopaedics and Related Research 2011, 469(10):2874-2880.

14. Yuan X, Li B, Wang Q, Zhang X: Comparison of 3 Routes of Administration of Tranexamic Acid on Primary Unilateral Total Knee Arthroplasty: A Prospective, Randomized, Controlled Study. Journal of Arthroplasty 2017, 32(9):2738-2743.

15. Heyns M, Knight P, Steve AK, Yeung JK: A Single Preoperative Dose of Tranexamic Acid Reduces Perioperative Blood Loss: A Metaanalysis. Annals of surgery 2020. 
16. Higgins JPT GS: Cochrane Handbook for Systematic Reviews of Interventions Version 5.1.0. London, UK: The Cochrane Collaboration. Cochrane handbook org 2011.

17. Higgins JPGS: editor. Cochrane collaboration. Cochrane handbook for systematic reviews of Interventions. West Sussex: Wiley; 2008.

18. Egger M, Davey Smith G, Schneider M, Minder C: Bias in meta-analysis detected by a simple, graphical test. BMJ (Clinical research ed) 1997, 315(7109):629-634.

19. Xie J, Hu Q, Huang Q, Ma J, Lei Y, Pei F: Comparison of intravenous versus topical tranexamic acid in primary total hip and knee arthroplasty: An updated meta-analysis. Thrombosis Research 2017, 153:28-36.

20. MacGillivray RG, Tarabichi SB, Hawari MF, Raoof NT: Tranexamic acid to reduce blood loss after bilateral total knee arthroplasty: a prospective, randomized double blind study. The Journal of arthroplasty 2011, 26(1):24-28.

21. Fillingham YA, Ramkumar DB, Jevsevar DS, Yates AJ, Shores P, Mullen K, Bini SA, Clarke HD, Schemitsch E, Johnson RL et al: The Efficacy of Tranexamic Acid in Total Knee Arthroplasty: A Network Meta-Analysis. Journal of Arthroplasty 2018, 33(10):3090-+.

22. Wang HY, Wang L, Luo ZY, Wang D, Tang X, Zhou ZK, Pei FX: Intravenous and subsequent long-term oral tranexamic acid in enhancedrecovery primary total knee arthroplasty without the application of a tourniquet: A randomized placebo-controlled trial. $B M C$ Musculoskeletal Disorders 2019, 20(1).

23. Takuya Iseki ST, Motohiro Wakui, Shinichi Yoshiya: Intravenous tranexamic acid only versus combined intravenous and intra-articular tranexamic acid for perioperative blood loss in patients undergoing total knee arthroplasty. European journal of orthopaedic surgery \& traumatology : orthopedie traumatologie 2018:1-6.

24. Lee SY, Chong S, Balasubramanian D, Na YG, Kim TK: What is the Ideal Route of Administration of Tranexamic Acid in TKA? A Randomized Controlled Trial. Clinical Orthopaedics and Related Research 2017, 475(8):1987-1996.

25. Wei W, Dang S, Duan D, Wei L: Comparison of intravenous and topical tranexamic acid in total knee arthroplasty. Bmc Musculoskeletal Disorders 2018, 19.

26. Gomez-Barrena E, Ortega-Andreu M, Padilla-Eguiluz NG, Pérez-Chrzanowska H, Figueredo-Zalve R: Topical intra-articular compared with intravenous tranexamic acid to reduce blood loss in primary total knee replacement: a double-blind, randomized, controlled, noninferiority clinical trial. Journal of bone and joint surgery American volume 2014, 96(23):1937-1944.

27. George J, Eachempati KK, Subramanyam KN, Reddy AVG: The comparative efficacy and safety of topical and intravenous tranexamic acid for reducing perioperative blood loss in Total knee arthroplasty- A randomized controlled non-inferiority trial. Knee 2018, 25(1):185-191.

28. Tzatzairis T, Drosos GI, Vogiatzaki T, Tilkeridis K, Ververidis A, Kazakos K: Multiple intravenous tranexamic acid doses in total knee arthroplasty without tourniquet: a randomized controlled study. Archives of Orthopaedic and Trauma Surgery 2019, 139(6):859-868.

29. Lacko M, Cellar R, Schreierova D, Vasko G: Comparison of intravenous and intra-articular tranexamic acid in reducing blood loss in primary total knee replacement. Eklem Hastaliklari Ve Cerrahisi-Joint Diseases and Related Surgery 2017, 28(2):64-71.

30. Castro-Menendez M, Pena-Paz S, Rocha-Garcia F, Rodriguez-Casas N, Huici-Izco R, Montero-Vieites A: Efficacy of 2 grammes of intravenous transexamic acid in the reduction of post-surgical bleeding after total hip and knee replacement. Revista espanola de cirugia ortopedicay traumatologia 2016, 60(5):315-324.

31. May JH, Rieser GR, Williams CG, Markert RJ, Bauman RD, Lawless MW: The Assessment of Blood Loss During Total Knee Arthroplasty When Comparing Intravenous vs Intracapsular Administration of Tranexamic Acid. Journal of Arthroplasty 2016, 31(11):2452-2457.

32. Motififard M, Tahririan MA, Saneie M, Badiei S, Nemati A: Low Dose Perioperative Intravenous Tranexamic Acid in Patients Undergoing Total Knee Arthroplasty: A Double-Blind Randomized Placebo Controlled Clinical Trial. Journal of blood transfusion 2015, 2015:948304-948304.

33. Aguilera X, Martinez-Zapata MJ, Hinarejos P, Jordan M, Leal J, Gonzalez JC, Monllau JC, Celaya F, Rodriguez-Arias A, Fernandez JA et al: Topical and intravenous tranexamic acid reduce blood loss compared to routine hemostasis in total knee arthroplasty: a multicenter, randomized, controlled trial. Archives of Orthopaedic and Trauma Surgery 2015, 135(7):1017-1025.

34. Kim TK, Chang CB, Kang YG, Seo ES, Lee JH, Yun JH, Lee SH: Clinical value of tranexamic acid in unilateral and simultaneous bilateral TKAs under a contemporary blood-saving protocol: a randomized controlled trial. Knee Surgery Sports Traumatology Arthroscopy 2014, 22(8):1870-1878.

35. Bidolegui F, Arce G, Lugones A, Pereira S, Vindver G: Tranexamic Acid Reduces Blood Loss and Transfusion in Patients Undergoing Total Knee Arthroplasty without Tourniquet: A Prospective Randomized Controlled Trial. The open orthopaedics journal 2014, 8:250254. 
36. Lee SH, Cho K-Y, Khurana S, Kim K-I: Less blood loss under concomitant administration of tranexamic acid and indirect factor Xa inhibitor following total knee arthroplasty: a prospective randomized controlled trial. Knee Surgery Sports Traumatology Arthroscopy 2013, 21(11):2611-2617.

37. Aguilera X, Martinez-Zapata MJ, Bosch A, Urrútia G, González JC, Jordan M, Gich I, Maymó RM, Martínez N, Monllau JC et al: Efficacy and safety of fibrin glue and tranexamic acid to prevent postoperative blood loss in total knee arthroplasty: a randomized controlled clinical trial. Journal of bone and joint surgery American volume 2013, 95(22):2001-2007.

38. Maniar RN, Kumar G, Singhi T, Nayak RM, Maniar PR: Most Effective Regimen of Tranexamic Acid in Knee Arthroplasty: A Prospective Randomized Controlled Study in 240 Patients. Clinical Orthopaedics and Related Research 2012, 470(9):2605-2612.

39. Lin PC, Hsu CH, Huang CC, Chen WS, Wang JW: The blood-saving effect of tranexamic acid in minimally invasive total knee replacement: Is an additional pre-operative injection effective? Journal of Bone and Joint Surgery - Series B 2012, 94 B(7):932-936.

40. Molloy DO, Archbold HAP, Ogonda L, McConway J, Wilson RK, Beverland DE: Comparison of topical fibrin spray and tranexamic acid on blood loss after total knee replacement: a prospective, randomised controlled trial. Journal of bone \& joint surgery - british volume $2007,89(3)$.

41. Camarasa MA, Ollé G, Serra-Prat M, Martín A, Sánchez M, Ricós P, Pérez A, Opisso L: Efficacy of aminocaproic, tranexamic acids in the control of bleeding during total knee replacement: A randomized clinical trial. British Journal of Anaesthesia 2006, 96(5):576-582.

42. Good L, Peterson E, Lisander B: Tranexamic acid decreases external blood loss but not hidden blood loss in total knee replacement. British Journal of Anaesthesia 2003, 90(5):596-599.

43. Veien M, Sørensen JV, Madsen F, Juelsgaard P: Tranexamic acid given intraoperatively reduces blood loss after total knee replacement: a randomized, controlled study. Acta anaesthesiologica Scandinavica 2002, 46(10):1206-1211.

44. Tanaka N, Sakahashi H, Sato E, Hirose K, Ishima T, Ishii S: Timing of the administration of tranexamic acid for maximum reduction in blood loss in arthroplasty of the knee. Journal of bone \& joint surgery - british volume 2001, 83(5):702-705.

45. Benoni G, Lethagen S, Fredin $\mathrm{H}$ : The effect of tranexamic acid on local and plasma fibrinolysis during total knee arthroplasty. Thrombosis Research 1997, 85(3):195-206.

\section{Figures}




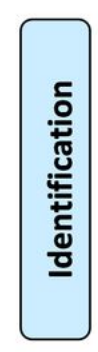

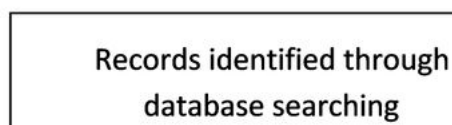

database searching

$$
(n=1754)
$$
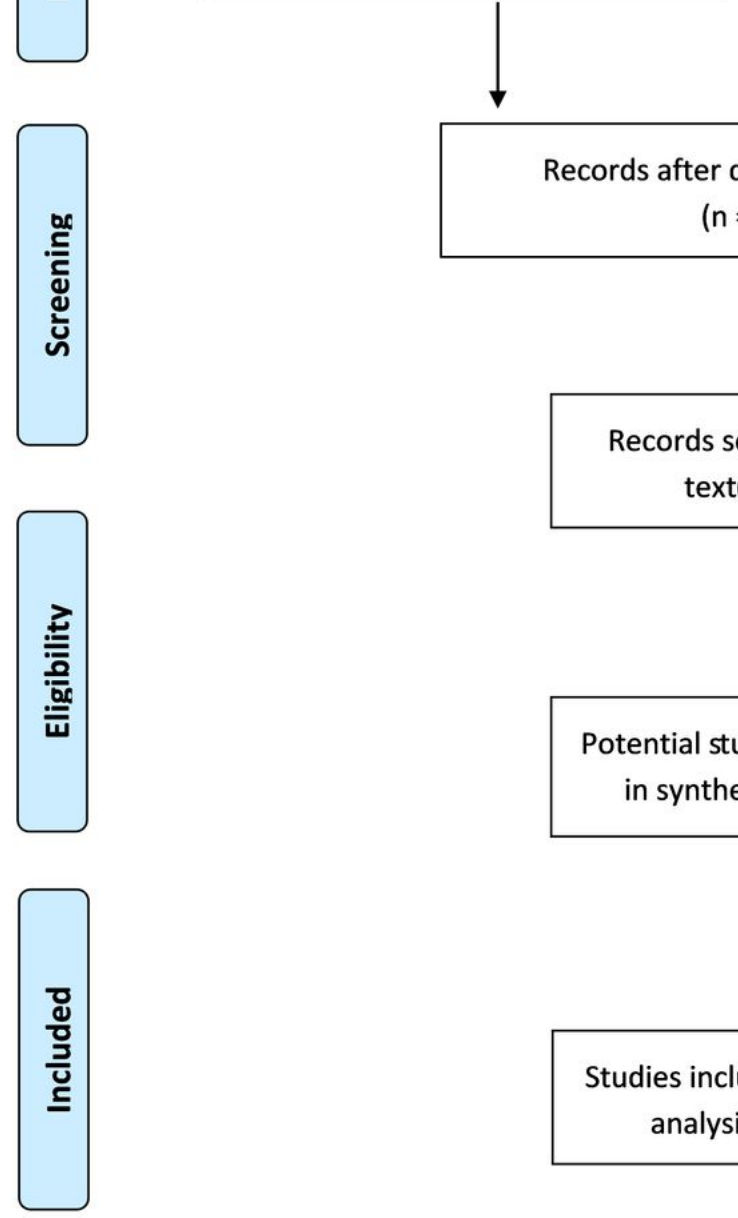

Records after duplicates removed ( $n=1251)$

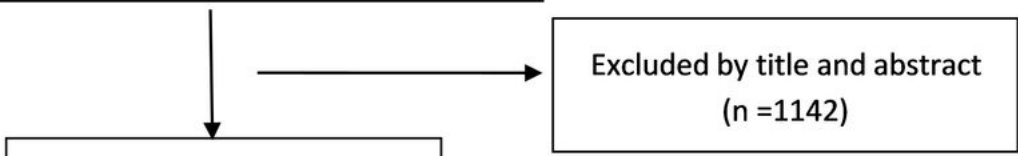

Records screened by full

text $(n=109)$

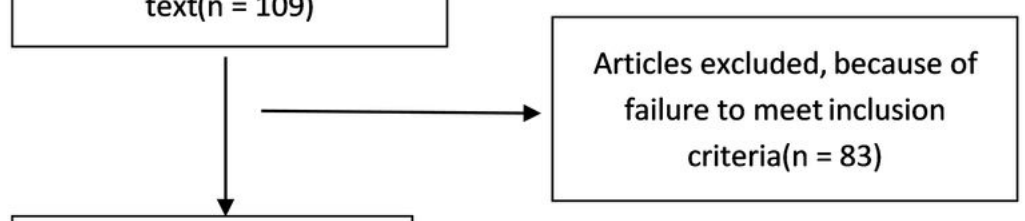

Potential studies included

in synthesis $(n=26)$

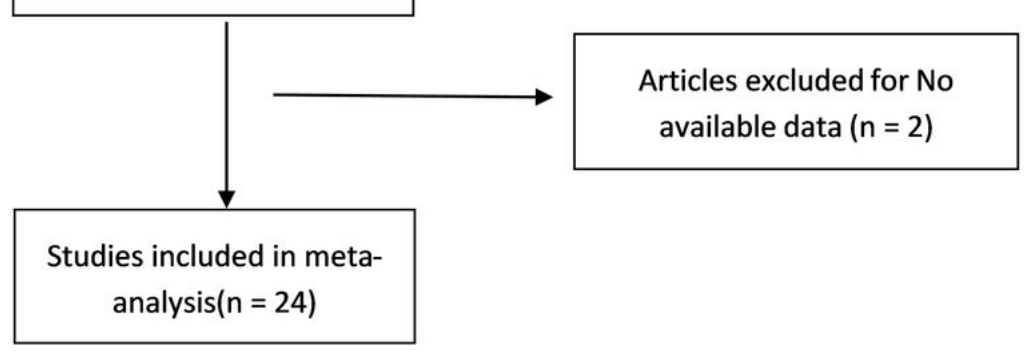

\section{Figure 1}

Flowchart of the study selection process 


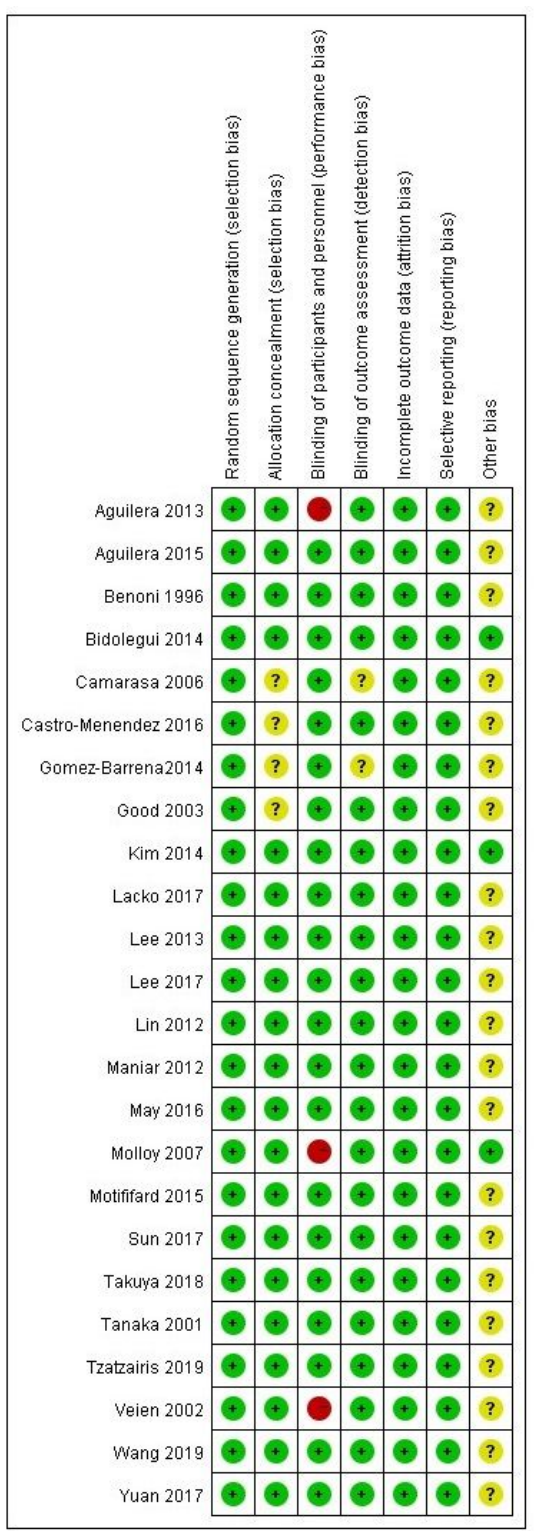

Figure 2

Risks of bias summaries 


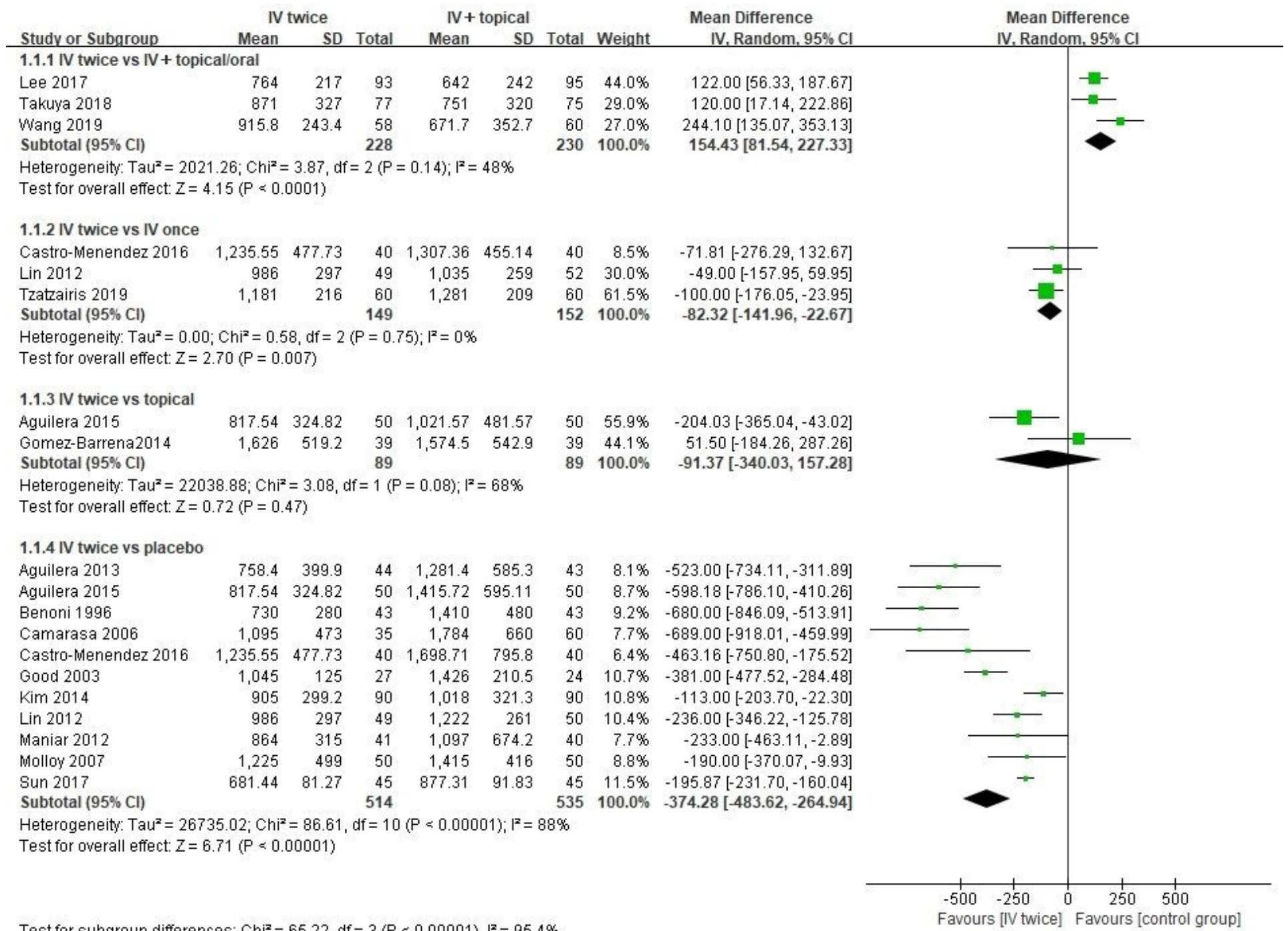

\section{Figure 3}

Forest plot showing postoperative blood loss 
IV twice control group

Risk Ratio

Risk Ratio

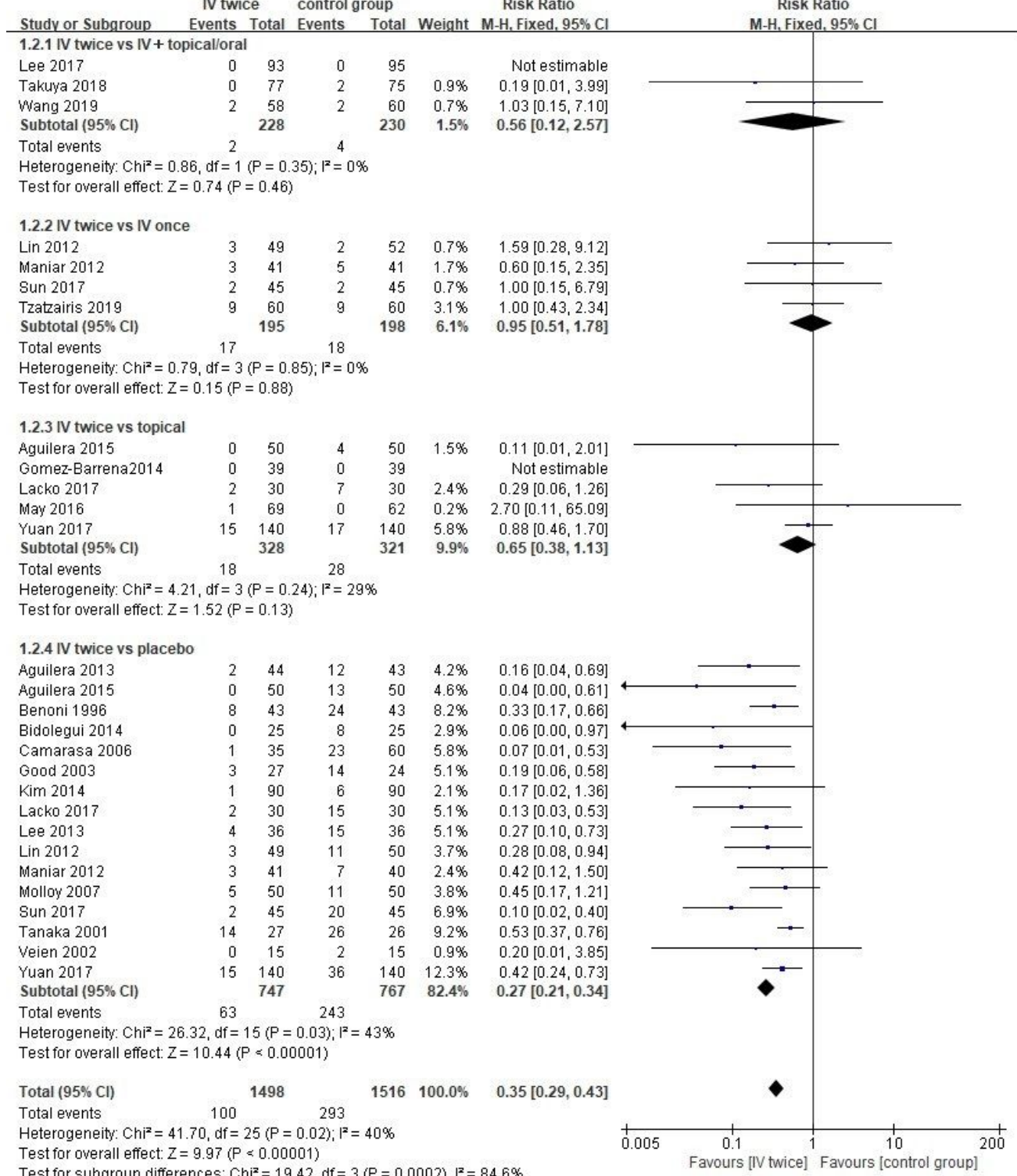

\section{Figure 4}

Forest plot showing transfusion rate 
IV twice Control Risk Ratio Risk Ratio

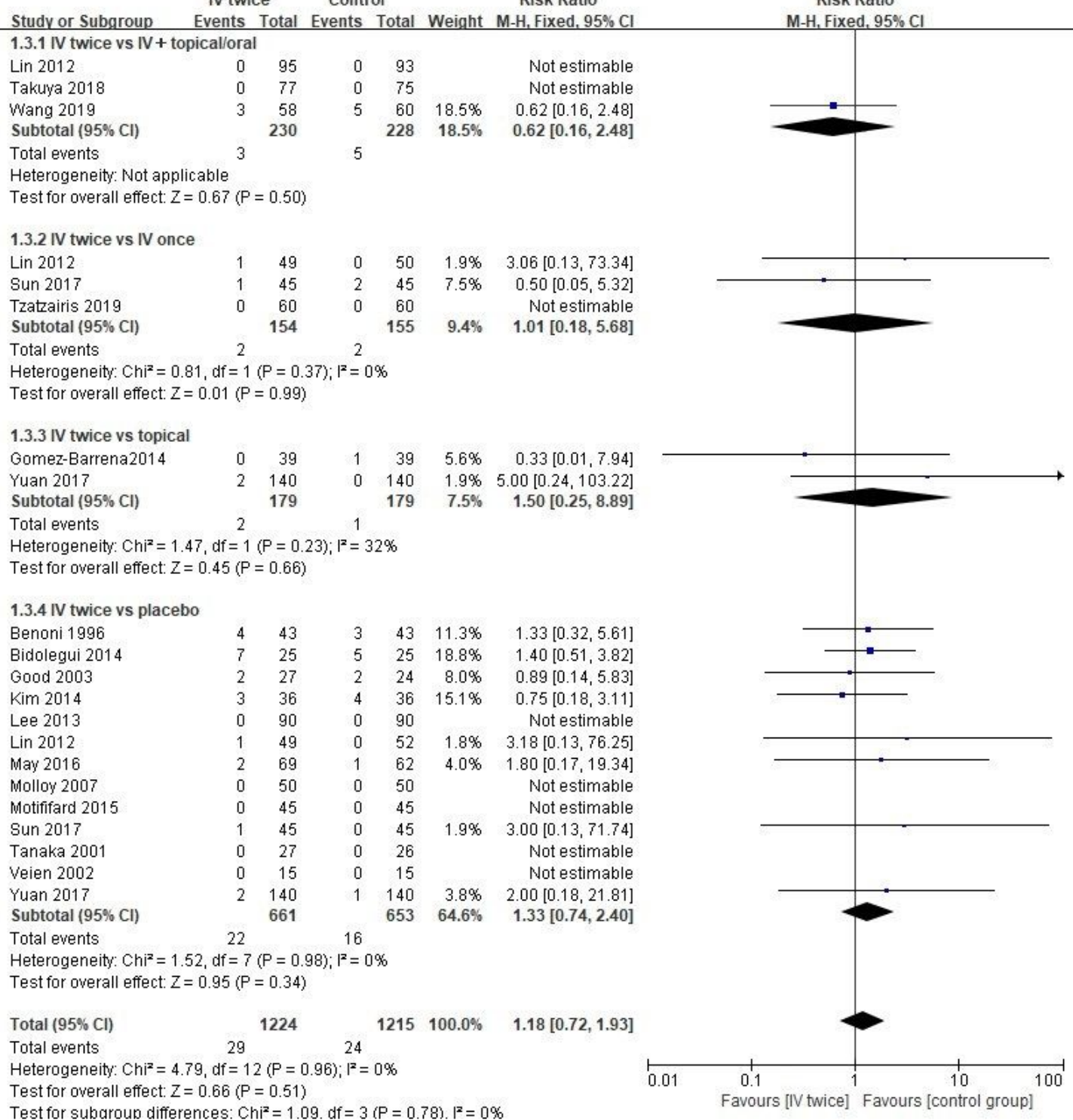

Test for subaroun differences: $\mathrm{Chi}^{2}=1.09 . \mathrm{df}=3(\mathrm{P}=0.78) . \mathrm{I}^{2}=0 \%$

Figure 5

Forest plot showing DVT Incidence

\section{Supplementary Files}

This is a list of supplementary files associated with this preprint. Click to download.

- SupplementSearchstrategy.docx 